\title{
A Prague Poem on Purgation? \\ Five Languages in a Seventeenth Century \\ IRISH MANUSCRIPT
}

\author{
Ken Ó Donnchú
}

\section{Introductionh}

The $17^{\text {th }}$ century was a profound disaster in political and military terms for Gaelic Ireland. It began with the defeat of the combined Irish and Spanish forces at the Battle of Kinsale in 1601, followed soon after by the exile of the most powerful native lords from Ulster in 1607. By mid-century, Oliver Cromwell had laid waste to large areas of the country as his Model Army set about subduing uprising and rebellion. The end of the century saw the final great hope of the Gaeil, the restoration of the house of Stuart, receive a fatal blow at the Battles of the Boyne and Aughrim. The Treaty of Limerick in 1691 precipitated the exodus of the so-called Wild Geese, the defeated Irish soldiers who left the country to seek military service in continental armies not engaged in hostilities with Britain. Traditionally, then, the $17^{\text {th }}$ century is recognised as the end of Gaelic Ireland, when much of the native elite was either killed, exiled, or reduced to poverty, and through plantation and repression, the majority Catholic population was relegated to a position of political and economic subservience to an English, Protestant minority.

As has been noted however (e.g. Ó Maonaigh 1962: 182), despite the catastrophic events of the $17^{\text {th }}$ century, few other eras in Irish history can offer much to compare to the literary achievements of that age. Irish historical writings are particularly prominent: in the period 1632-36 a group of scholars led by Franciscan friar Míchéal Ó Cléirigh completed the largest collection of Irish annals ever produced, Annála Rioghachta Eireann, the so-called Annals of the Four Masters (AFM). While obviously of huge historical importance, annals are rarely counted upon to provide much by way of literary merit-Osborn Bergin, for example, rejected them as "dull and colourless things" (1970: 22). Nevertheless, AFM is noteworthy for its tendency to expand upon events where other collections of Annals merely contain succinct obituaries. Of a more mundane character, but of equal value for Irish history is the great book of genealogies of an Dubhaltach Mac Fhirbhisigh, the compilation of which was finalised in 1650.

In the same years as AFM was being compiled, for the first time ever an Irishman undertook to write a complete history of the island in the Irish language-beginning with the faintest mythological remnants and continuing down 
until the coming of the Normans in 1169 AD. The result of this endeavour was the highly-influential Foras Feasa ar Eirinn (A Foundation of Knowledge of Ireland) by Séathrún Céitinn (Geoffrey Keating).

Naturally, however, not all $17^{\text {th }}$ century texts were of such scope, dimensions, or ambition. The curious composition which is examined below certainly does not meet any such criteria, and has thus (understandably) been largely neglected by Irish schol-

ars. Considering the likelihood of its Franciscan provenance, however, the words of Fr. Paul Walsh (1933: 96) come to mind: "Irish Catholicism and Irish Nationality owe so much to the great Franciscans of the $17^{\text {th }}$ century that it is desirable that every scrap in the shape of literature that they produced should be made accessible". In what follows, an edition of this particular "scrap" is presented, and its contents discussed. While the poem itself is unlikely to be added to the canon of Irish literature, nevertheless a number of aspects of its contents are intriguing, and invite investigation and restrained speculation as to the context of its production.

\section{Subject matter}

The poem in question is entitled 'Freagra ar et cætera Philip' (An Answer to Philip's Et Catera, FCP hereafter) in its unique manuscript witness, University College Dublin (UCD) Franciscan Collection MS A32 f. 5r. Apart from the short description contained in the catalogue of the Franciscan Collection (Dillon et al. 1969: 69), Cainneach Ó Maonaigh is the only scholar to have commented on the contents of this poem (1940: 181; 1962: 197). The poem centres on the 'evacuation' difficulties of one Philip Ó Conaill, the hardship this has caused those in his company, and the advice given to Philip on how to cure his ailment. 'Evacuation', though synonymous with 'defecation' (i.e. expelling bodily waste through the anus) is used here in a broader sense, to refer to the lack of clarity in the poem regarding Philip's ailment. Although the poem refers specifically to a "stomach without ... protection", "noise in your hole", "no obstruction in your body to stools", and then bemoans the purgation utilised as a cure, it is never entirely clear whether the unfortunate Philip has suffered diarrhoea, constipation (hence the purgation), or simply flatulence. All three seem to be amalgamated into a general complaint of Philip's bout of ill health. Nevertheless, the tenor of the poem is quite clear, and the particulars of Philip's sickness don't require strict definition for the poem's intent to be understood.

In medieval and early modern medicine, the practice of purgation, and the use of clysters were both common. Purgation sought to cleanse the body of "an excess of morbid humours" through "laxation, perspiration, vomiting, opening of body pores" (Norri 2016: 893). Purgation by laxation is described in FCP. Directions regarding the use of clysters (the preferred treatment, according to the poem's author) are provided. Recent research on Irish medical manuscripts (de Vries 2019, Hayden 2019), building on the work of Nic Dhonnchadha $(2004,2006)$, has shown 
that various cures and remedies from foreign sources had been firmly adapted to the Irish medicinal context by the late middle ages. FCP cannot be said to derive from this tradition. Yet, it provides an interesting comparandum to the 'official' medical manuscript sources. It would appear that although the medical content is not in itself the primary focus of the poem, the advice it prescribes is nonetheless an essential part of the poem's message.

In literary terms, FCP exemplifies the strong interest of the Irish literati at all stages in so-called Rabelaisian humour, and burlesque literature. The Early- and Middle-Irish tales Cath Maige Tuired and Aislinge Meic Con Glinne, the slightly-later Tromdám Guaire, and the modern compositions Pairlement Chloinne Tomáis (1 $17^{\text {th }}$ century) and Cúirt an Mheon-Oiche ( $18^{\text {th }}$ century), as well as the late barántas-genre, all attest to sustained engagement with such humour. Again, while it is to be noted that FCP is far shorter (and of far less literary significance) than any of the former texts, the thematic continuity, even in general terms, is of interest. Before examining the possible context of the poem's composition, the particulars of the unique manuscript witness, namely date, provenance and contents, will be outlined.

\section{Manuscript}

The folio containing FCP has been described by Dillon et al. (1969) in their catalogue of the Franciscan Collection of Irish language manuscripts. This collection, previously held by the Franciscans in Killiney, is now housed at University College Dublin. According to the catalogue (p. xxiv), continental European provenance is to be ascribed to the majority of the manuscript in question, A32, and the particular folio containing FCP (folio 5). Unfortunately, as this is a composite manuscript (i.e. containing folios bound together which in origin are all possibly independent of each other) it is very difficult to assess what relation (if any) these folios have to each other. The catalogue also states that the majority of UCD Franciscan MS A32 dates to the $17^{\text {th }}$ century. Ó Maonaigh has argued that a date in the second half of that century is to be attached to this folio. We shall return to his dating below. The scribe of the text is unknown.

The subject of the poem, the ill health of Philip Ó Conaill, and the cure suggested to him, are presented in the form of a light satire on the person of Philip. The identification of the satire's target as 'Philip Ó Conaill' is based on Ó Maonaigh's proposal that the name and surname mentioned in the first and second stanzas of the poem are one and the same person. This proposal is accepted here and followed throughout. Ó Maonaigh's proposed identification of Philip Ó Conaill is also discussed below. Additionally, a certain 'Anthonio Conmaes', whose name appears on the verso of UCD Franciscan MS A32 folio 5, will also be taken into account.

A normalised edition and translation of the text here follows. 


\section{Text $^{1}$}

\section{Freagra ar Et Cætera Philip [UCD Franciscan Collection MS A32 f.5r.]}

Truagh leamsa Philip,

fa thinnios sa mbaile shíos.

Is truagh leam a bhinid,

le deintheas gan díon.

Truagh leam Uí Chonuill, an torunn atá 'do thóin.

Truagh leam gan stópuinn, i do chollunn ar stól.

Truagh leam gar minic, do tharruinn don bhaile siar.

Is truagh leam go deimhein,

mar shaluigh tú mo chliar.

Do shaluigh tú Réamonn, 's ní fearr do Mhac na Midhe.

Is d'fhágais ó do bhréantoll, iad araon 'na luidhe etc.

An phróis sin do tháinic ort, is géar a loit do bhrú.

's mur' beith a dhéine stop, do bheitheá anocht san uaigh.

1. Doubtful manuscript readings (especially in the case of the Czech stanza) and other emendations are discussed in the semi-diplomatic edition of FCP in Ó Donnchú (forthcoming). I am most grateful to Jason Harris, Hynek Janoušek, Radvan Markus, Simon Böckle, Pádraig Ó Macháin, and Ondřej Pilný for their assistance in preparing this edition. All remaining errors are my responsibility. 


\section{Translation}

\section{An Answer to Philip’s Et Cætera}

I pity Philip,

in sickness below at home.

I pity his stomach,

with urgency [and] without protection.

I pity O'Connell,

the noise that is [in] your hole

I regret there's no obstruction

in your body to stools.

I regret that you often

head back towards the town.

Indeed I regret it,

for you defiled my clergy.

You defiled Réamonn,

and it's no better for Mac na Midhe

And your putrid hole

left them both prostrate etc.

That prowess that came upon you,

severely it ruined your bowels.

And if it were not for how quickly it stopped

tonight you would be in the grave. 
Angar ar an bpurgóid,

do rinne urchóid dot' thóin.

Nár lór dhí mar phiolóid,

bheith fa thrioblóid gan feoil.

Mar sin dob fhearr an clisteire,

do chur timchioll ann do thóin.

Iná bheith ag caitheamh do ghidirne,

le himioll gach stóil etc.

$\begin{array}{ll} & \text { If you will do no more, } \\ \text { be sure the poppy must do your feast. } & \text { For it will be, or you will see, } \\ \text { before this year your death etc. } & \\ \text { Ich was neit, } & \text { was hadt der Philipp gehabt in sain Cupf. } \\ & \text { Ven er hadt so fiel, } \\ \text { su mir gesaght fon sain brust. } \\ \text { Germanice } \\ \text { Bože můj Philippe, } \\ \text { pro Pána Boha. } \\ \text { Deite mi chliba, } \\ \text { deite mi máku } \\ \text { Contra dolores a purgatione relictos. } \\ \text { Tubam fumiferam tobacci sume Philippe } \\ \text { accipe clisterium. Liquida nulla time. } \\ \text { Confortat cerebrum clisterium, cæera membra } \\ \text { disponit, refouet uiuificatque senem. } \\ \text { Hæc modo sufficiant; sint cæera vestra retorta. } \\ \text { Cætera si dederis; cætera plura time. etc. }\end{array}$


Woe to the purgative

that maligned your arse.

Wasn't it torment enough

to suffer for want of meat?

Thus it was better to put the clyster inside around your hole,

than to be wearing [out] your arse

against the edge of every stool etc.

If you will do no more,
be sure the poppy must do your feast.
For it will be, or you will see,
before this year your death etc.
I don't know what
Philip had in his head
when he said so much
to me from his heart.
My God Philip,
for God's sake.
Give me bread,
give me a poppy.
Against the Pains that Remain after Purgation
Take a smoking tube of tobacco, Philip.
Accept the clyster. Don't worry, there's no liquid
involved.
The clyster will ease your mind, set your other parts
in order, rekindle and revive your old age.
If these things work, throw away your other stuff;
if you do apply other things, beware of more to come.
etc.




\section{The language question}

While passages of Latin are common in Irish texts from the very beginning of the literary tradition, a composition as multilingual as FCP in an Irish manuscript is extremely rare. Ó Maonaigh (1962: 197) listed FCP among those $17^{\text {th }}$ century texts "[in which] the poet mixes various languages together for the purposes of ridicule". We might ask what exactly is the purpose of the intended ridicule; for instance, are multilingual texts themselves the target? Has the poet compiled a multilingual text, seeking to give the work a veneer of learning and earnestness, only to use it to discuss a trivial and seemingly ignoble subject? This will be addressed further below. Regarding the languages found in FCP, the presence of Latin, as mentioned above, is wholly unsurprising. Similarly, English is found in many Irishlanguage manuscripts during the classical period (c. 1200-1650). Mac Mathúna (2007: 218) notes that English is exploited as a source for literature and general information by Irish scribes with increasing regularity from the end of the $15^{\text {th }}$ century. However, the inclusion of text in German and Czech in an Irish-language manuscript is highly unusual.

Isolated words in German are to be found in an Irish-language medical manuscript of the late $16^{\text {th }}$ century (TCD 1437; cf. Abbot and Gwynn 1921: 317). ${ }^{2}$ Possibly the longest example of continuous German text in an Irish-language manuscript is in the famous account given by Tomás Ó Caiside of his wanderings in Europe around the middle of the $18^{\text {th }}$ century (Nic Philibín 1938: 33; cf. Mac Cárthaigh 2013). These amount to a very small quantity of short sentences, however.

Regarding Czech, I know of no other example of this language to be found in any extant Irish-language manuscript. This should not surprise us, of course; it is notable that the so-called 'Czech lands' (cf. Power and Pilný 2014) are rarely referenced in Irish literature. The kingdom of Bohemia is mentioned at the beginning of Fis Mheirlino (The Vision of Merlino, Macalister 1905: 5; see also Hegarty 2018: 122), but this isn't necessarily a specific reference to Bohemia. Kingdoms mentioned at the commencement of vision texts are often understood as unknown, far-away regions, as opposed to specific geographical areas (cf. the comments of Bruford (1969: 21-22) in relation to the Irish Romantic tradition). In similar vein, while other references may point to an Irish familiarity with the kingdom of Bohemia, the relevant texts in fact fall into two categories: (1) translations from other languages such as Latin (Beatha San Froinsias, Ó Súilleabháin 1957), or Spanish (An Irish Corpus Astronomiae, O’Connell and Henry 1915); (2) adaptations of instructional texts originally written in other languages, such as Eólas ar an Domhan by Tadhg Ó Neachtáin (Ní Chléirigh 1944).

Nevertheless, important links between Ireland and the 'Czech lands' were forged in the $17^{\text {th }}$ century. The presence of an Irish Franciscan house in Prague for

2. I am indebted to Aoibheann Nic Dhonnchadha for this information. 
over 150 years, from 1629 to 1786, constitutes some of the most substantial evidence of Irish-Slavic relations in the $17^{\text {th }}$ and $18^{\text {th }}$ centuries. It should be noted that this wasn't the only such effort to enhance Irish-Slavic cooperation. A similar attempt at founding a Franciscan house in Wieluń, Poland, in the mid-17 $17^{\text {th }}$ century was also made, but was ultimately unsuccessful. This Polish arrangement was "very precarious from the beginning", and documents detailing its failed mission are few (Jennings 1957: 38). While the Prague foundation never achieved the same level of renown as that of the Irish house in Louvain (cf. Millett 1964: 493), nonetheless, significant works of piety and scholarship emerged from the Prague Irish Franciscan community. Unfortunately, while much of what was written (and printed) in Latin by the Prague Irish Franciscans has survived, no Irish-language manuscript written in Prague has been preserved there, or indeed anywhere else in the Czech Republic. The vast majority of these manuscripts have consequently shared the fate of so many other Irish manuscripts, being variously dispersed, damaged, or lost to obscurity (cf. Dillon 2007; Mac Craith and Worthington 2002).

Despite this, there appears to be a strong possibility that FCP was composed in Prague. Certain historical facts lend support to this proposal. Throughout the $17^{\text {th }}$ century, and for a long time after that, both German and Czech were spoken in Prague (and, indeed, throughout the 'Czech lands'). In the 1620s, German was given official parity of status with Czech (Parker 2006: 59). The occurrence of both Czech and German in an Irish-language manuscript is more readily conceived of if a Prague provenance is considered. While a religious setting appears the most likely context for such a composition, the reference to 'mo chliar' ('my clergy') in the third stanza, coupled with the poem's preservation in a Franciscan manuscript, suggest further support for this proposal.

Two further points are worth mentioning: (1) however basic the knowledge of medical practices presented in FCP may appear, Irish medical students were present in Prague in the $17^{\text {th }}$ century, and they maintained a close relationship with the Prague Irish Franciscans (Pařez and Kuchařová 2015: 11-3). To suggest that it was from his medical compatriots that the putative Franciscan composer of FCP received instruction is perhaps stretching credulity, but this information is nonetheless of relevance (the 'medical' aspect of FCP is discussed further in Ó Donnchú (forthcoming)); (2) Pařez and Kuchařová (2015: 61) mention a certain Louis MacNamie, a Franciscan sent to Prague from St Anthony's in Louvain in September 1633. MacNamie's exact identity cannot be ascertained (by me, at any rate) but is he possibly to be identified with the 'Mac na Midhe' mentioned in stanza 4 of FCP? A further possibility regarding 'Mac na Midhe' is discussed below.

With regard to the composer of FCP, how are we to interpret his acquisition of five different languages? If we accept the proposal that he was a Franciscan, then we can assume that he was educated largely through Latin. It would seem 
overwhelmingly likely that Irish was his native language, thus accounting for both of the longest sections of the poem. The evidence for the remaining three languages, a single stanza in each, is admittedly rather slight, and the remarks that follow bear the important caveat that it would be unwise to read too much into this testimony. It is entirely possible that he was exposed to English either from childhood, that is, being raised in a bilingual environment, or through education.

As Bernadette Cunningham has observed in relation to the Jesuit priest John Lynch's work Cambrensis Eversus (1662): 'while Irish was the primary language of everyday conversation [i.e. in the $17^{\text {th }}$ century], literate people probably knew English and perhaps Latin' (Cunningham 2018: 436-7). He displays a solid grasp of German orthography, but it is difficult to avoid the impression that he wasn't as fluent in Czech as he was in the former languages (cf. Ó Donnchú (forthcoming)). Being a mendicant order, the Franciscans were dependent on the public for alms. Thus, an ability to communicate in the vernacular(s) was of fundamental importance to their success everywhere they went. While this cannot be given as definitive proof of a Prague provenance for FCP, the likelihood of each of these languages being present, to greater or lesser degrees, in the everyday lives of the Irish Franciscan community in Prague is at the very least suggestive of such an origin.

\section{Other texts}

Textual support for this proposal, that FCP was composed in Prague, is difficult to find. Two particular texts, of very different lengths, found in a manuscript which we know to have been composed in Prague, present a similar linguistic mélange. This engagement with language is worth exploring. The manuscript in question is now preserved in the Niedersächsische Staats- und Universitätsbibliothek, Göttingen, Germany (8 Cod. Ms. hist. 773). The signature of Fr[ater] Antonie Úa Conchabhair on folio $108 \mathrm{v}$ is dated 2 December 1659, and places him in the Irish Franciscan house in Prague. 8 Cod. Ms. hist. 773 contains 186 folios, among them historical prose texts, such as the first book of Keating's Foras Feasa ar Eirinn, a short grammatical and poetical tract in Latin, as well as pious poetry, much of it composed by Franciscans.

Of specific interest to our investigation of FCP are two poetic items in this manuscript. The first of these, Deórchaóineadh na hEireann (The Tearful Lament for Ireland) is an enumeration of the calamities suffered by Éire ever since "the children of Israel were in captivity in Egypt” (Mhág Craith 1967: 252; cf. Thurneysen 1893: 154). Like much of the poetry preserved in this manuscript, Deórchaóineadh na hÉreann was composed by a Franciscan. In this instance its composer, Séamas Carthún, is said to have done so during his incarceration in Ireland in 1651 (Mhág Craith 1967: 252). The only surviving copy of the poem is in the Göttingen manuscript. The 145-line Irish text is followed by abbreviated versions in English ('Irland's Lamentation') and Latin ('Lamentatio Hiberniae'), respectively. It is of interest that 
although this poem was not composed in Prague, its single manuscript witness is an Irish Franciscan manuscript written in Prague, and later taken to Germany, in circumstances now unknown. When taken together, Deórchaóineadh na hÉireann, and its English and Latin translations/adaptations, form a reasonably lengthy text, and point to arguably more than a passing interest in multilingualism on the part of the copyist. In contrast to this, the second example of a multilingual text in this manuscript is a mere four lines in length. Nevertheless, the treatment of language in this single stanza, noted in passing by previous commentators (Ó Maonaigh 1962: 197; O’Rahilly 1925: 3), is worthy of closer examination, especially in the context of FCP. The stanza reads as follows:

Non licet in hac vita a bheith parcus duiairc

but briefly still giving as spagadh an chruiais

Íosa a los que piden do bheir talluinn uait

dion maoineach ar an tsháoghal so don tshagairt chrúaidh

(8 Cod. Ms. hist. 773 f. 1v; cf. O’Rahilly 1923: 97; 1925: 3)

It is not permitted in this life to be mean and gloomy

but briefly still giving from the purse of hardness

Jesus, to those who ask, you give talluinn

[Grant] a precious sheltering in this life to the hard-up priest

${ }^{*}$ talluinn: talents/sustenance?

Differences of style, layout, length and subject matter between 'Non licet in hac vita' (NL henceforth) and FCP are immediately apparent. The arrangement and distribution of languages also distinguishes the poems. Whereas FCP's composer has arranged his poem in discrete sections according to the language in which they are written (listing the four sections that are not written in Irish in a Latinised form of each language's name), NL's author freely mixes languages within a single line of text. Thus the final line of the stanza is the only one containing a single language, Irish. In lines 1-3 Irish is mixed with Latin, English and Spanish (which it bookends), respectively, to give something more akin to the so-called macaronic songs of the post-classical period in Ireland (Ó Muirithe 1980: 25-8).

Despite such differences, however, some important similarities are to be noted. The Franciscan context of the manuscript, and the likelihood that a Franciscan also composed NL, draw our attention again to the multilingual abilities of these men. It is apparent that the composer is deriving some satisfaction (in spite of his stanza being a petition) from his language admixture. Deórchaóineadh na hEireann, found 
in the same manuscript, is of a more doleful character still, but some sense of enjoyment (or consolation?) from this use of languages is difficult to avoid. In the absence of further textual evidence, it is impossible to reach definitive conclusions, but the likelihood that FCP and NL were composed in the same cultural milieu, and in the same city, is worthy of consideration.

\section{Textual genre and language use}

In a short note on FCP, primarily focused on identifying Philip Ó Conaill, Ó Maonaigh described the poem as a Rabelaisian composition (1940: 81). As often with such descriptions, there is little consensus as to what exactly constitutes a Rabelaisian text. In the case of Irish-language literary criticism, Máirtín Coilféir has demonstrated that the term is understood quite differently by critics who analyse the work of writers "[that] differ immensely in their approach, their subject matter, their style, even their humor" (2016: 211). Following Markus (2015: 136) I understand the term 'Rabelaisian' as generally according with aspects of the definition proposed by Bakhtin (1984: 21): a focus on, and explication of carnal desires and bodily functions in the context of civilised, polite and respectable discourse. The aim of this is very often to parody the supposedly civilised matter at hand. Human faeces, for example, or the functions of the nether region of the human body are frequently discussed in such texts (cf. Markus 2015: 136). In FCP, the bodily function element is very prominent, but carnal desires are absent.

Whatever degree of Rabelaisian influence we wish to attach to FCP, as a poetic composition it is evidently more than mere doggerel. The language element, both in the sense of how the author deals with the Irish language specifically, and his decision to add four further languages to the Irish text, alerts us to some purpose other than simple mockery. As Ó Maonaigh notes (1962: 197), it appears that the author of FCP is mixing different languages in his composition for the purpose of ridicule, and possibly to produce what could be viewed as pseudo-learned or sophisticated writing, despite the apparently 'improper' nature of the text's subject. The tenor or nature of this ridicule of Philip is worth noting. As Mercier has remarked: "lampoon is by far the commonest type of Gaelic satire; just as the old spells were naturally directed against individuals or specific groups, the newer satires name names and attack individuals rather than universal vices or follies" (1962: 7). FCP can be seen to agree with this, in general terms. It names the target of its lampooning, Philip, but does not lay the blame for his plight entirely on said target. While repeatedly expressing his regret at Philip's actions ['Truagh liom' "I pity"], the author doesn't wish to subject Philip to the "direct, contemptuous attack" so typical of Irish language satires (Ó hÓgáin 1982: 307). Rather, the unfortunate choice of cure (purgative), and the apparent lack of "obstruction in your body to stools" are equally lamented, although neither purgative nor control over evacuation can be termed as 'universal vices or follies'. 
Regarding the author's treatment of the Irish language text of FCP, in keeping with the overall lightly satirical tenor, certain items of vocabulary call for examination. Such an examination can help reveal something of the author's mentality and aims. For example, the word binid in stanza 1 has the basic meaning of 'rennet', but is here translated in its transferred sense of 'stomach'. The use of metonymy implies a more subtle approach than we might have expected, given the subject matter. The author, it would seem, preferences a word with distinct animal associations, as opposed to words commonly used to refer to the stomach (e.g. goile, bolg). In doing so, however, he is not directly calling Philip an animal (cf. McLaughlin 2008: 33-39, for animal terminology in Early- and Middle-Irish satire).

We might expect a variety of terms to be used when referring to parts of the lower half of the body in a so-called Rabelaisian text. The most commonly used word in Modern Irish for buttocks, tóin, appears three times in FCP, alongside the very rarely documented gidirne [cf. FGB s.v. geidirne], and what is possibly a compound of the author's own making, the word bréantoll, meaning 'putrid [bréan] hole [toll]'. Such a compound is reminiscent of those found in the popular $17^{\text {th }}$ century satire Pairlement Chloinne Tomáis, where characters and kindreds based on forms of the word broim 'fart' (genitive case bromalbrama) people the text, e.g. Giolla Pádruig Ó Braimpléisge, Riocard Rúnolcach Ó Ramharbhrama, and Sliocht Mhannarthaig an Bhrama (Williams 1981: 185-194).

Perhaps the most interesting item of the Irish vocabulary of FCP is the word for faeces, stól. Again, where the common cac may have been expected, our text would appear to bear witness to the emergence of an alternative phrasing (it is of interest that $F G B$ does not preserve this meaning of stól). While other examples of stól in the sense of FCP are to be found in a small number of printed editions of texts (a single example each in Stair Eamuinn Ui Chléire, and in a poem by Dáibhí Ó Bruadair), unpublished medical manuscript sources contain further attestations. Aoibheann Nic Dhonnchadha has kindly provided me with examples from medical manuscripts dating to the early $15^{\text {th }}$ century of the phrase 'ag dul chum stoil' meaning 'to go to stool, to void'. 'Similar to the use of different languages in FCP, the choice of lexical items in the Irish section of the text is suggestive of both the author's concern for language use, and his linguistic adaptability.

\section{Humour and bodily functions in Irish literature}

A modern reader might reasonably expect an element of lampoon and humour in a Rabelaisian text which makes frequent reference to certain parts of the lower half of the human body. Humour, with rare exceptions, is an understudied area of Irish literature. To take the view of 'Rabelaisian' elements being present in Early

3. E.g. National Library of Ireland MS G 11, 197, Royal Irish Academy MSS 24 P 26, 150, 24 P 14, 147. 
Irish literature (anachronisms aside) for the purposes of humour would be misguided, according to the thesis put forward by Doris Edel. Having examined both the aspect of bodily functions and desires in Early Irish literature, Edel presents the following conclusion: "In early Irish literature, the bodily matters are handled in an unembarrassed manner. They form an integral part of the delineation of the characters... Sexual and excretory activities are part of the development of the plot" (2006: 101-2). She perceives an important change in the treatment of this aspect of Irish literature after the $12^{\text {th }}$ century: "in Ireland, the decline of the artistic level after the flowering of the Old Irish period - a flowering that continued to a certain extent into the Middle Irish period - left a vacuum which was subsequently filled, by want of better, by more crudely-fashioned works" (Edel 2006: 102).

Without mentioning specific texts to exemplify this turn towards "crudely-fashioned works", one suspects that such incidents as the following from Acallamb na Senórach (Stokes 1900: 153) are the sort Edel has in mind: "ro chraith in cú a herboll, co tainic gaeth doilf drai[d]echta as, co ro thoitsetar a sceith da inguillib a slega assa lamaib 7 a claidme da slessaib...", 'the hound shook its tail, and a magical wind came from it, so that their shields fell from their shoulders, and their spears from their hands, and their swords from their thighs' [my translation]. In this incident, a female hound of the Fian, Fer Mac, has attacked and laid low Donn and Dubán, sons of the king of Ulaid, by raising her tail and farting in their direction. According to Edel's thesis, such an incident, had it occurred in an Early Irish text, would form a central and "unembarrassed" element in the story's narrative. Acallamh na Senórach is generally taken to have been composed close to or immediately preceding the beginning of the Early Modern Irish period, but draws heavily on earlier traditions. To entirely disregard the potential element of humour, however crude, in this incident, in preference to the pragmatics of the narrative, is possibly taking Edel's thesis to extremes. Of course there are manifest dangers in comparing literary texts composed in different eras, regardless of the element of linguistic continuity. Edel focuses primarily on prose texts of the Early Irish period (c. 700-950 AD), whereas FCP is, by my estimation, a poem from the third quarter of the $17^{\text {th }}$ century at the earliest. It is worth noting there are relevant considerations which lend possible support to Edel's view of bodily functions in the early literature. Uraicecht Becc, a legal tract on status dating to the Early Irish period (cf. Binchy 1958: 48, Breatnach 2005: 316) lists among the category of professional entertainers the bra[i]getoir, the professional farter. This term, and the related braigire, are also mentioned in the Tech Midchuarta text in the Book of Leinster (cf. Downey 2010). Slight as this evidence may be, a similarity in functional terms is suggested here, i.e. that the bodily function practiced by the bra[i]getoir and the braigire is not simply an instance of something humorous, but a reflex of the practical application of that function. 


\section{Philip Ó Conaill and Anthonio Conmaes}

I suggest that FCP was written in the Irish Franciscan house in Prague in the years closely preceding or following the activity of Antonie Úa Conchabhair, as witnessed in the Göttingen manuscript described above (1659). Accordingly, I suggest the date range 1650X1670. Given the manuscript context of FCP (see above) and the lack of authorial signature, this suggestion is based largely on other considerations, such as a comparison with the linguistic profile of select texts in the Göttingen manuscript. We do not know who the author of FCP was, nor can we say if author and scribe were one and the same person. It is entirely possible, indeed, that the scribe of FCP was dictating the various verses from different people, i.e. that no single multilingual 'author' is responsible for FCP, but at least two people. Of course, there is no way of determining the veracity of such a suggestion. Of people named both in FCP, and in the three lines of text on the verso of that folio of manuscript, we have at least some material to interrogate.

Ó Maonaigh (1940: 181) proposed that the Philip Ó Conaill mentioned in our poem was the same Philip O'Connell who was guardian of the Franciscan convents in Lislaughtin, Co. Kerry, and Adare, Co. Limerick, at various times between 1661 and 1681 (cf. Giblin 1956: 65, 116, 129, 152). This Philip O'Connell was the target of a satirical poem by Dáibhí Ó Bruadair in 1679 (Mac Erlean 1913: 206; cf. Binéid 2003: 47). We cannot say if this is the same Philip O'Connell who was in the Irish Franciscan College of San Isidoro in Rome in 1663, a "former soldier, who was then a novice and at the same time acting as a cook" (Millett 1964: 125). The mention of "novice", however, in contrast to the "guardian" of Lislaughtin and Adare, makes it highly unlikely to be the same Philip O’Connell in both cases.

In some ways, however, greater importance is to be attached to a different man, whose name is mentioned in the three lines of text on the verso of the folio (UCD MS A32 f.5) in question. The three lines read as follows (pace Dillon et al. 1969: 69): "Venerando Br. fri. Anthonio Conmaes ordinis minorum Strictioris observantiae Theolog(iae?). Freagra an so ar et caetera Philipp”. Who was Anthonio Conmaes? Ó Maonaigh refers to an "Anthony Conmaes... who figures under different forms of this name in the Chapter Acts from the years 1699 to 1735" (1940: 181). There, however, Ó Maonaigh ends his inquiries, and doesn't seek to locate Conmaes in any particular Franciscan community. The range of dates in the sources relating to Franciscans of this name would suggest that more than one Anthonio Conmaes was active among that religious community in the $17^{\text {th }}$ and $18^{\text {th }}$ centuries. We know, for example, that there was an Anthony Conmaes at the Irish Franciscan house in Louvain in 1648 (Jennings 1968: 161). He is mentioned in Franciscan letters from the years 1651, 1653, 1654 and 1656, during which time he remained in Louvain, it seems. He is referred to as "sacrae theologiae lector et collegii discretus" in the letters from 1653 and 1654 (Jennings 1968: 171, 176, 186, 200). It is unclear from the Chapter Act of 1699 
where Anthony Conmaes was based (Giblin 1956: 230), but Franciscan sources record a "venerandus pater frater Antonius Conmy" at Louvain in 1702 (Jennings 1968: 324).

Was this the same Conmaes present at Louvain in 1648? The description as "venerandus" (cf. 'venerando', UCD MS A32 f.5v.) would suggest that it possibly was. It is unlikely, however, that the Conmaes whom Ó Maonaigh mentions as being recorded in the Chapter Acts up to the year 1735 is the same person. The last recorded date I have found for an Ant[h]onio (Anthony etc.) Conmaes is 1714, and the location of this man was the Irish Franciscan house in Boulay, France (Giblin 1956: 336). For our purposes here, the dates of this Anthonio Conmaes pose a difficulty for the dating of FCP; the $1650 \mathrm{X} 1670$ range I propose is considerably earlier than the 1699X1735 range which Ó Maonaigh mentions.

One further question merits examination. 'Conmy' (Latinised as Conmaes) is one of the English versions of the surname Mac Conmheadha/Mac Con Meadha (Woulfe 1923: 341). This surname is very close to another surname, Mac Con Midhe (> Mac na Midhe). Could the reference in stanza 4(b) of FCP to 'M[h]ac na Midhe' possibly refer to Anthonio Conmaes? Ó Maonaigh's brief note on FCP concluded with a question: if FCP was the 'answer/reply' (freagra), what or where is the original 'Et Caetera' of Philip? This question remains to be resolved, as do those relating to the identities of Philip Ó Conaill and Anthonio Conmaes.

\section{Conclusion}

However seriously we choose to take the satirising of Philip in FCP, the fact that such reproaches were being made among Irish Franciscans in the $17^{\text {th }}$ century should come as no surprise to us. The history of the Prague Irish Franciscan community published by Pařez and Kuchařová (2015) is replete with accounts of hostile exchanges. These extended from in-house disputes, to inter-provincial disagreements. One such difference of opinion has survived in the form of a letter written by four Irish Franciscans in Prague, dated 6 March 1641. In the letter, the brothers complain that the Louvain house has undertaken a campaign of dishonouring and ruining the good name of the Prague Irish Franciscans. Specifically, the Prague house has been accused of drunkenness, wrongly, they insist:

[A]ta ar cclú ar na spotadh, agus ar na dubhadh a cconveint Lobháin... as truagh agus as olc linn ar ndearbraithre dar ngonadh. Do tuiceamar as litreachaibh aithreach Lobháin, go spéisialta ó dhis acu, gurab é a meas atá ar an áitse nach bfuil innte acht táibherne photairidhe mar nach [bfuil] dexersís againn acht na copáin.

(Walsh 1933: 194-195; Dillon 2007: 64) 
[O]ur reputation is being stained and blackened in the Louvain convent. We pity and we grieve that our brothers are wounding us. We understand from letters of the Louvain fathers, particularly from two [of the fathers], that their view of this place is that it is only a tavern of drunkards, as our only exercise is the [raising of] cups [my translation].

Unfortunately, no further correspondence relating to this affair has survived. Nevertheless, the general context of this letter fits what we have been examining here in the case of FCP. As acknowledged at the beginning, a text like FCP will never attain canonical status in Irish literature. However, that is not to say that such a text is not valuable for other reasons. Stray items such as FCP and the letter quoted above attest to the daily experiences of an exiled Irish community in the $17^{\text {th }}$ century. They reveal something of the human element which other literary sources may not necessarily capture. A reaction to accusations of drunkenness, for example, is likely to be more revealing in terms of personality and public perception, say, than any number of religious tracts or grammatical treatises. Equally, the gentle satirising of a man suffering the effects of an ill-advised purgation highlights the fact that such religious communities lived in close-quarters, without the luxury of modern plumbing. If my proposal is correct, FCP would appear to belong to the meagre category of Prague Irish-language literary survivals, all of which are now preserved outside of the Czech Republic. In illustrating the quotidian struggles of the age in which it was written, it reminds us also of the variety of texts extant among the vast array of Irish writing produced in the tumultuous $17^{\text {th }}$ century.

University College Cork

\author{
Abbreviations \\ FCP = Freagra ar et cætera Philip, UCD Franciscan Collection MS A32 f. 5r \\ FGB = Ó Dónaill 1977 \\ $\mathbf{N L}=$ Non licet in hac vita, Niedersächsische Staats- und Universitätsbibliothek, \\ Göttingen, 8 Cod. Ms. hist. 773 f. $1 \mathrm{v}$
}

\title{
References
}

Abbot, T.K., \& Gwynn, E.J., 1921, Catalogue of the Irish Manuscripts in the Library of Trinity College, Dublin, Dublin: Hodges, Figgis, \& Co.

Bakhtin, M., 1984, Rabelais and His World, trans. H. Iswolsky, Bloomington: Indiana University Press. 
A PRAGUE POEM ON PURGATION?

Bergin, O., 1970, Irish Bardic Poetry: Texts and Translations, together with an Introductory Lecture, Dublin: DIAS.

Binchy, D.A., 1958, 'The Date and Provenance of Uraicecht Becc', Ériu 18, 44-54.

Binéid, D., 2003, Searc na Suadh: Gnéithe de fhiliocht Dháibhi Ui Bhruadair [Love of the Learned: Aspects of Dáibhí Ó Bruadair's Poetry], Baile Átha Cliath: Clóchmhar Tta. Breatnach, L., 2005, A Companion to the Corpus Iuris Hibernici, Dublin: DIAS.

Bruford, A., 1969, Gaelic Folk-tales and Mediaeval Romances: A Study of the Early Modern Irish 'Romantic Tales' and their Oral Derivatives, Dublin: The Folklore of Ireland Society.

Coilféir, M., 2016, “'Cold, Mocking, Unmerciful?” Rabelasianism in Irish Literature', American Journal of Irish Studies 13, 197-213.

Cunningham, B., 2018, 'Language, Literature, and Print in Irish, 1630-1730'. In: Ohlmeyer, J., ed., The Cambridge History of Ireland, Volume II, 1550-1730, Cambridge: Cambridge University Press, 434-457.

de Vries, R., 2019, 'A Short Tract on Medicinal Uses for Animal Dung', North American Journal of Celtic Studies 3 (2), 111-136.

Dillon, C., 2007, 'Catalóg Leabharlann na bProinsiasach Éireannach, Prág' [Catalogue of the Library of the Irish Franciscans, Prague], Léann 1, 63-76.

Dillon, M., Mooney, C., \& de Brún, P., ed., 1969, Catalogue of Irish Manuscripts in the Franciscan Library, Killiney, Dublin: DIAS.

Downey, C., 2010, 'Dindsenchas and the tech midchuarta', Eriu 60, 1-35.

Edel, D., 2006, “Bodily Matters' in Early Irish Narrative Literature', Zeitschrift für celtische Philologie 55, 69-107.

Giblin, C., ed., 1956, Liber Lovaniensis: a Collection of Irish Franciscan Documents, 1629-1717, Dublin: Clonmore and Reynolds.

Hayden, D., 2019, 'Attribution and Authority in a Medieval Irish Medical Compendium', Studia Hibernica 45, 19-51.

Hegarty, C., 2018, Fis Mheirlino: A Diplomatic Edition with Introduction and Notes, Ulster University, unpublished PhD Thesis.

Jennings, B., 1957, 'The Irish Franciscans in Poland', Archivium Hibernicum 20, 38-56.

Jennings, B., ed., 1968, Louvain Papers, 1606-1827, Dublin: Stationery Office.

Macalister, R.A.S., ed., 1905, Fis Mherlino: The Vision of Merlino, an Irish Allegory, Dublin: M.H. Gill.

Mac Cárthaigh, E., 2013, 'Ó Caiside, Tomás Bán', in: Dictionary of Irish Biography (available at https://doi.org/10.3318/dib.006292.v1 [last accessed 14 Jun 2021]).

Mac Craith, M., \& Worthington, D., 2002, 'Aspects of the Literary Activity of the Irish Franciscans in Prague, 1620-1786'. In: O’Connor, T. \& Lyons, M.A., ed., Irish Migrants in Europe after Kinsale, 1602-1820, Dublin: Four Courts, 118-134.

Mac Erlean, J.C., 1910-17, Duanaire Dháibhidh Ui Bhruadair [Collection of Dáibhidh Ó Bruadair's Poetry] i-iii. London: Irish Texts Society. 
Mac Mathúna, L., 2007, 'The growth of Irish (L1)/English (L2) Literary Code-mixing, 1600-1900: Contexts, Genres and Realisations'. In Tristram, H.L.C., ed., The Celtic Languages in Contact: Papers from the Workshop within the Framework of the XIII International Congress of Celtic Studies, Bonn, 26-27 July 2007, Potsdam: Potsdam University Press, 217-234.

Markus, R., 2015, '“Chac na Cuileoga ar a Shoilse an tImpire”: Breandán Ó hEithir, Oirthear na hEorpa agus an Dea-Shaighdiúir Švejk' [The Flies Shat on His Excellency the Emperor: Breandán Ó hEithir, Eastern Europe and the Good Soldier Švejk]. In: Nic Congáil, R., Nic Eoin, M., Ní Úrdail, M., Ó Liatháin, P., \& Uí Chollatáin, R., ed., Litriocht na Gaeilge ar fud an Dombain. Imleabhar II: Critic, Cultúr agus Combthéacs Comhaimseartha [Irish Literature around the World. Volume II: Criticism, Culture and Contemporary Context], Baile Átha Cliath: An Clóchomhar Tta, 125-145.

McLaughlin, R., 2008, Early Irish Satire, Dublin: DIAS.

Mercier, V., 1969, The Irish Comic Tradition, London: Oxford University Press.

Mhág Craith, C., 1967, Dán na mBráthar Mionúr [Poetry of the Friars Minor], Baile Átha Cliath: Institiúid Árd-Léinn Bhaile Átha Cliath.

Millett, B., 1964, The Irish Franciscans, 1651-1665, Rome: Gregorian \& Biblical Press. Nic Dhonnchadha, A., 2004, 'Téacs ó scoil leighis Achaidh Mhic Airt' [A Text from the Aghmacart Medical School], Ossory, Laois and Leinster 1, 56-75.

Nic Dhonnchadha, A., 2006, 'The Medical School of Aghmacart, Queen's County', Ossory, Laois and Leinster 2, 11-43.

Ní Chléirigh, M., eag., 1944, Tadhg Ó Neachtain. Eólas ar an Domhan i bhfuirm chombráidh idir Sheán Ó Neachtain agus a mhac Tadhg [Information About the World in the Form of Conversation Between Seán Ó Neachtain and his Son Tadhg], Baile Átha Cliath: Oifig an tSoláthair.

Nic Philibín, M., 1938, Na Caisidigh agus a gCuid Filidheachta [The Cassidys and their Poetry], Baile Atha Cliath: Oifig an tSoláthair.

Norri, J., 2016, Dictionary of Medical Vocabulary in English, 1375-1550: Body Parts, Sicknesses, Instruments, and Medicinal Preparations, London/New York: Routledge.

O’Connell, F.W., \& Henry, R.M., 1915, An Irish Corpus Astronomiae being Manus O'Donnell's Seventeenth Century Version of the Lunario of Geronymo Cortès, London: D. Nutt.

Ó Dónaill, N., ed., 1977, Foclóir Gaeilge-Béarla [Irish-English Dictionary], Baile Átha Cliath: Oifig an tSoláthair.

Ó Donnchú, K., forthcoming, “"Freagra ar et cætera Philip”-Dán Ilteangach ón Seachtú hAois Déag' ["Freagra ar et cætera Philip”- a Seventeenth Century Multilingual Poem]. In: Markus, R., Nic Eoin, Nic Mhathúna, D., Ní Mhuircheartaigh, É., Ó Conchubhair, B., \& Ó Liatháin, P., eag., "Ar an Imeall i Lár an Domhain?”Litriocht agus cultúr na hÉireann agus na hEorpa-Nascanna staire, teanga, cultúir agus litriochta ["On the Edge in the Middle of the World?" Irish and European Literature and Culture-Historical, Linguistic, Cultural and Literary Links]. 
Ó hÓgáin, D., 1982, An File: Staidéar ar Osnádúrthacht na Filiochta sa Traidisiún Gaelach [The Poet: A Study of the Supernatural in Poetry in Gaelic Tradition], Baile Átha Cliath: Oifig an tSoláthair.

Ó Maonaigh, C., 1940, 'Father Philip Ó Conaill, O.F.M.', Irish Book Lover 27 (2), 181. Ó Maonaigh, C., 1962, 'Scríbhneoirí Gaeilge an Seachtú hAois Déag' [Irish Language Writers of the Seventeenth century], Studia Hibernica 2, 182-208.

Ó Muirithe, D., 1980, An tAmhrán Macarónach [The Macaronic Song], Baile Átha Cliath: An Clóchomhar Tta.

O'Rahilly, T.F., 1923, 'Burduin Bheaga' [Short Epigrams], The Irish Monthly 51 (596), 95-97.

O’Rahilly, T.F., 1925, Bürduin Bheaga: Pithy Irish Quatrains, Dublin: Browne \& Nolan. Ó Súilleabháin, P., 1957, Beatha San Froinsias [Life of Saint Francis], Baile Átha Cliath: Institiúid Árd-Léinn Bhaile Átha Cliath.

Pařez, J., and Kuchařová, H., 2015, The Irish Franciscans in Prague 1629-1786, Prague: Karolinum Press, Charles University.

Parker, G., 2006, The Thirty Years' War, London: Routledge.

Power, G., \& Pilný, O., ed., 2014, Ireland and the Czech Lands: Contacts and Comparisons in History and Culture, Bern: Peter Lang.

Stokes, W., 1900, 'Acallamh na Senórach'. In: Stokes, W., \& Windisch, E., eds., Irische Texte iv (i), 1-438.

Thurneysen, R., 1893, 'La Lamentation de l'Irlande', Revue Celtique 14, 153-162.

Walsh, P., 1933, Gleanings from Irish Manuscripts, Dublin: Three Candles.

Williams, N., ed., 1981, Pairlement Chloinne Tomáis [The Parliament of Clann Tomáis], Baile Átha Cliath: Institiúid Árd-Léinn Bhaile Átha Cliath.

Woulfe, P., 1923, Sloinnte Gaedheal is Gall: Irish Names and Surnames, Dublin: M. H. Gill. 